\title{
PELELANGAN PROYEK KONSTRUKSI BERBASIS INTERNET
}

\author{
Maksum Tanubrata, Hendaryanto Wiryopranoto \\ Dosen Jurusan Teknik Sipil, Fakultas Teknik, Universitas Kristen Maranatha \\ Jalan Suria Sumantri 65, Bandung, 40164 \\ e-mail: maksum.tanubrata150@gmail.com
}

\begin{abstract}
Procurement implementation by auction can be done efficient, effective and comparable, transparent, fairness, not discriminative and accountable with the system which can accommodate the above criteria. With the fast development of information technology the above implementation can be realized with the online auction system base on internet by web. E-procurement, it is an application for auction implementation by electronic with internet basis where web as an implementation medium. This application can be used as an announcement, document storage also as a tool in selection process. With internet base the interaction between buyers and vendors can be optimized without any limitation in distance and time.
\end{abstract}

Keywords: efficient, effective, transparent, E-Procurement.

\section{LATAR BELAKANG}

Dalam menyikapi era globalisasi pemerintah berupaya melakukan perubahan dalam peraturan proses pelelangan pekerjaan konstruksi dimana proses pelelangan pekerjaan konstruksi diharapkan menjadi lebih efisien, efektif, terbuka, bersaing, transparan, adil dan akuntabel. Seiring dengan kemajuan teknologi maka proses pelelangan yang selama ini dilaksanakan secara offline dapat berevolusi menjadi proses pelelangan yang online karena dapat mendukung prosers pelelangan yang memenuhi kriteria yang diinginkan. Untuk itu perlu dilakukan E-Procurement, yaitu pelaksanaan pelelangan konstruksi berbasis internet.

Pelelangan secara online merupakan salah satu dari kemajuan teknologi informasi yang perkembangannya di Indonesia kurang begitu pesat, khususnya dalam pelelangan pekerjaan konstruksi, sehingga sangat diharapkan setelah adanya perubahan peraturan dalam proses pelelangan pekerjaan konstruksi, pelelangan pekerjaan konstruksi secara online mulai dapat diimplementasikan dan diaplikasikan secara lebih luas di masa mendatang.

\section{E-PROCUREMENT}

E-Procurement merupakan aplikasi dari pelaksanaan pelelangan secara elektronik berbasis internet. Aplikasi ini dapat berfungsi untuk media pengumuman, tempat penyimpanan dokumen sekaligus sebagai alat bantu dalam proses seleksi. Sehingga 
interaksi antara buyers dan vendors dapat dilakukan secara optimal, tanpa ada batasan jarak dan waktu.

\section{Tingkatan dalam Proses Penyelenggaraan E-Procurement}

Penyelenggaraan aplikasi e-procurement memerlukan waktu serta proses bertahap, karena adanya perubahan kebiasaan kerja yang fundamental serta kesiapan seluruh komponen sistem yang terkait. Oleh karena itu, urutan logis dari penerapan $e$ procurement, dimulai dari aktivitas yang dampak efisiensinya paling besar, namun mudah pelaksanaannya yang dibagi dalam beberapa tingkatan.

\section{Tingkat Persiapan}

a. Pembuatan situs dengan aplikasi dasar e-procurement;

b. Pendidikan dan pelatihan sumber daya manusia menuju penerapan e-procurement;

c. Sosialisasi keberadaan aplikasi e-procurement, baik untuk publik maupun penggunaan internal;

d. Penyiapan peraturan pendukung.

\section{Tingkat Pematangan}

a. Pembuatan situs informasi layanan publik interaktif, antara lain dengan menambahkan fasilitas mesin pencari (search engine), fasilitas tanya jawab dan lain-lain;

b. Pembuatan hubungan dengan situs informasi lembaga lainnya (hyperlink).

\section{Tingkat Pemantapan}

a. Penyediaan fasilitas transaksi secara elektronik antara lain dengan menambahkan fasilitas penyerahan formulir, fasilitas pembayaran dan lain-lain yang menjamin konektivitas yang aman, handal, dapat diakses oleh masyarakat;

b. Penyatuan penggunaan aplikasi dan data dengan lembaga lain (interoperabilitas).

\section{INFRASTRUKTUR SITUS}

Dalam pembuatan situs diperlukan suatu infrastruktur untuk membangun situs tersebut. Infrastruktur ini digunakan sebagai sarana untuk meletakkan informasi dan layanan publik secara on-line. 
Infrastruktur situs merupakan gabungan perangkat keras dan lunak yang membentuk fasilitas dasar (platform) untuk kegiatan layanan publik yang dilakukan oleh suatu lembaga.

Infrastruktur situs meliputi jaringan komputer dan jaringan telekomunikasi yang menjamin konektivitas yang aman, handal, dapat diakses oleh masyarakat dan dapat digunakan sebagai media pertukaran informasi antar lembaga.

Aspek utama yang perlu diperhatikan di dalam mengembangkan infrastruktur situs adalah :

- Arah pengembangan infrastruktur informasi elektronik secara keseluruhan;

- Arah pengembangan jasa layanan publik secara keseluruhan;

- Arah pengembangan jenis layanan publik serta mitra dalam pembangunan dan pengoperasiannya.

Komponen utama dari suatu infrastruktur situs yang diperlukan adalah:

- Jalur fisik informasi;

- Aplikasi-aplikasi dasar untuk mendukung kegiatan front-office dan back-office;

- Jaringan informasi global (internet).

\section{JALUR FISIK INFORMASI}

Merupakan saluran komunikasi yang menghubungkan semua pengguna, baik di satu lembaga, maupun antar lembaga, dan antar daerah. Jalur fisik informasi selain merupakan penghubung antar seluruh wilayah dalam Negara Kesatuan Republik Indonesia, juga dapat dimanfaatkan untuk menyalurkan data dan informasi yang terhubung dengan jaringan informasi global (internet).

Jalur fisik ini dapat berupa jaringan yang menggunakan kabel (kawat tembaga, kabel listrik dan serat optik), frekuensi radio (fixed wireless, mobile wireless, broadband wireless) atau satelit (VSAT, narrowband mobile).

Pada umumnya, jalur fisik ini digunakan untuk menghubungkan berbagai perangkat elektronik dan komputer, yang dapat diklasifikasikan sebagai berikut :

* Jaringan lokal (Local Area Network - LAN)

** Jaringan metropolitan (Metropolitan Area Network-MAN)

*** Jaringan jarak jauh (Wide Area Network - WAN) 
* Merupakan jaringan komputer yang saling terhubung dalam satu gedung atau satu kompleks perkantoran yang berdekatan, yang digunakan untuk komunikasi data dalam suatu area kerja tertentu.

Peralatan minimum yang dibutuhkan untuk membangun LAN adalah server, workstation dan perangkat lunaknya, serta hub dan jalur komunikasi berupa kabel atau perangkat nirkabel.

Jaringan lokal pada umumnya digunakan untuk keperluan e-mail, mengakses basis data serta pertukaran file, data dan informasi.

** Merupakan jaringan komputer dengan cakupan area lebih luas daripada LAN. Pada umumnya MAN mencakup area satu kota yang dapat berupa gabungan dari sejumlah LAN yang terpisah. MAN terhubung dengan jalur transmisi yang dinamakan backbone.

*** Merupakan jaringan yang terdiri dari sejumlah MAN yang mencakup wilayah antar kota, antar propinsi, antar negara, dan bahkan antar benua untuk melakukan komunikasi data jarak jauh.

Persyaratan minimum untuk membangun WAN adalah server, workstation, hub, router dan jalur komunikasi berupa jaringan kabel atau perangkat nirkabel.

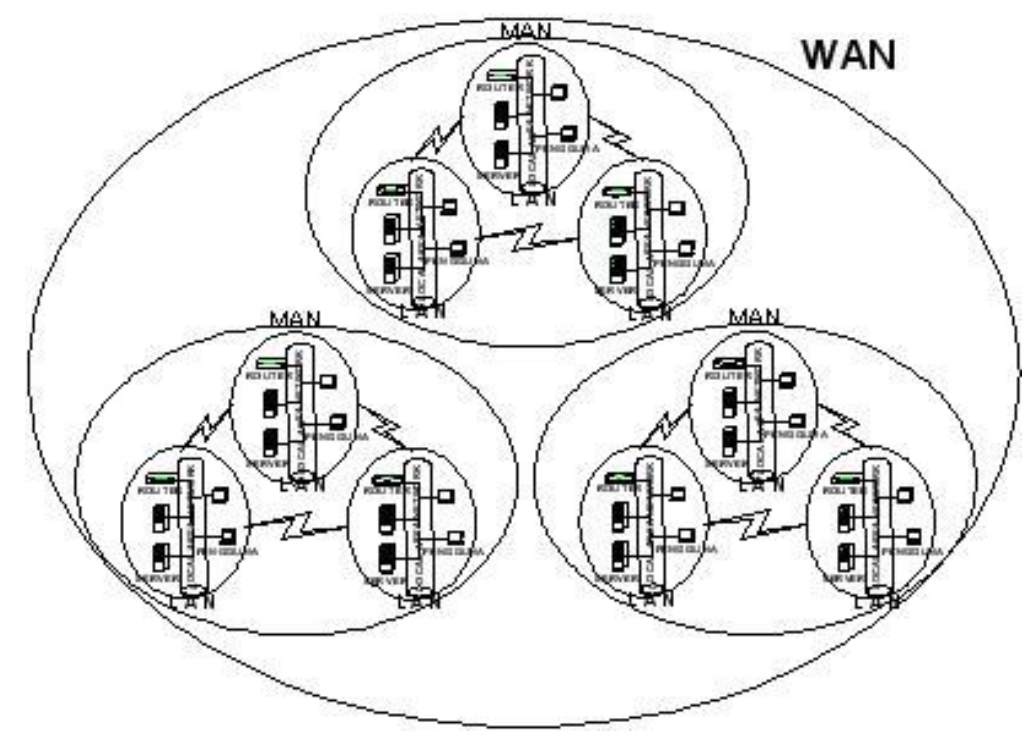

Gambar 1 : jalur Fisik Informasi

Adapun langkah-langkah yang perlu dilakukan untuk membangun jaringan fisik informasi adalah sebagai berikut:

Analisis terhadap tahapan dari layanan yang akan dibangun;

1. Menetapkan jenis jaringan informasi yang dibutuhkan; 
2. Menetapkan jaringan informasi yang perlu dibangun;

3. Menetapkan spesifikasi teknis dari seluruh perangkat yang dibutuhkan, meliputi:

a. Penentuan koneksi internal dan eksternal yang akan dipergunakan

b. Penentuan kebutuhan bandwidth sesuai dengan jenis layanan.

4. Menyusun studi kelayakan finansial dan ekonomi untuk masing-masing jenis layanan;

5. Mempersiapkan rencana implementasi.

\section{INTERNET}

Jaringan komputer global (internet) adalah kumpulan jaringan komputer yang saling terhubung dan menganut konsep terbuka, sehingga informasi yang ada di dalamnya dapat diakses secara luas. Internet menggunakan protokol komunikasi Transfer Control Protocol/Internet Proocol (TCP/IP).

Ketersediaan internet dapat dimanfaatkan sebagai media bagi masyarakat untuk mengakses informasi publik melalui Warung Internet (Warnet) ataupun Internet Service Povider (ISP). Selain itu internet dapat dimanfaatkan pula oleh lembaga pemerintah untuk mencari informasi global secara on-line dan menyebarluaskan informasi ke masyarakat dan manca negara.

\subsection{Sistem Keamanan Jaringan}

Keterhubungan suatu jaringan lokal dengan berbagai pihak secara global memerlukan berbagai perangkat pengaman untuk menghindari ancaman dari pihak yang tidak berhak mengaksesnya.

Pada suatu jaringan terbuka terdapat beberapa potensi yang membahayakan keamanan sistem, yaitu pada tingkat:

a. $\quad$ Sistem operasi (operating system - os), seperti virus.

b. Sistem jaringan, seperti penyadapan data pada jalur komunikasi dari, dan atau ke internet.

c. Sistem aplikasi seperti pengrusakan web, database.

Aspek yang perlu diperhatikan dalam mengelola suatu jaringan lokal atau intranet adalah:

- $\quad$ Adanya jaringan (network availability), sistem cadangan (redundancy system) dan sistem penanggulangan bencana (disaster recovery system);

- $\quad$ Adanya perangkat pengaman jaringan (network security); 
Adanya jaminan kehandalan jaringan (network reliability) terhadap beroperasinya suatu jaringan.

Suatu jaringan lokal secara umum harus memenuhi persyaratan sebagai berikut:

a. Privasi (privacy/confidentiality). Aspek ini berkaitan dengan kerahasiaan data, misalnya data pegawai negeri hanya boleh diakses oleh orang yang berhak.

b. Integritas (integrity). Data atau informasi tidak boleh berubah tanpa ijin dari pemilik dan tidak boleh diubah oleh orang yang tidak berhak.

c. Otentikasi (authentication). Aspek ini digunakan untuk menjamin keaslian data, sumber data, orang yang mengakses data dan server yang digunakan.

d. Ketersediaan (availability). Aspek ini menjamin bahwa data dan informasi harus tersedia saat diperlukan.

e. Riwayat kejadian (occurance history). Aspek yang menjamin bahwa seseorang tidak dapat menyangkal apabila dia telah melakukan suatu pertukaran informasi.

f. Pengendalian akses (access control). Aspek ini membatasi atau mengatur hak akses pengguna (siapa boleh melakukan apa). Berbagai langkah perlu diambil untuk menjamin keamanan terhadap hal-hal tersebut di atas:

g. Prosedur pengamanan. Menetapkan kebijakan dan prosedur untuk menjamin keamanan sistem dalam berinteraksi dengan pengguna.

h. Pengamanan fisik jaringan. Menggunakan firewall, intrusion detection system, anti virus dan virtual private network (vpn).

i. Pengamanan akses. Menggunakan password.

j. Otentikasi data/informasi yang dikirim. Menggunakan enkripsi.

k. Otentikasi penerima data/informasi. Menggunakan certification of authority (ca)/ public key infrastructure (pki).

1. Pengamanan data/record. Menetapkan prosedur manajemen sistem dokumen elektronik.

m. Pengamanan ruangan. Membatasi akses ke ruangan peralatan jaringan ditempatkan.

\subsection{Latar Belakang Pembuatan Dokumen Elektronik}

Hampir semua instansi saat ini masih menyimpan atau mengarsipkan dokumen dalam bentuk kertas. Praktek ini memiliki banyak kekurangan, antara lain : kemungkinan seorang staf lupa untuk mencetak dan mengarsipkan dokumen;

Selain itu dokumen elektronik yang sudah ada pun memiliki kekurangan seperti: 
- Pesan e-mail atau dokumen elektronik terhapus dari komputer tanpa diarsipkan sebelumya;

- Dokumen elektronik dari situs web dan intranet tidak terkontrol versi dan perkembangannya secara efektif;

- Tidak dapat mengelola dokumen multimedia (teks, gambar dan suara) secara terintegrasi.

Pengarsipan dokumen elektronik perlu dikelola secara elektronik untuk mendapatkan manfaat yang maksimal, antara lain :

- $\quad$ Pengumpulan informasi yang lebih baik, konsisten dan mudah dicari kembali;

- Memudahkan penggunaan dokumen secara bersama.

Dokumen dalam bentuk elektronik mudah dibuka dan ditelusuri isi dan riwayatnya, yang sebelumnya sulit dilakukan pada dokumen kertas.

Dokumen elektronik harus dikelola dengan baik untuk menjamin integritas, keabsahan, dan keasliannya. Dokumen elektronik yang berisi transaksi elektronik harus dijaga agar tetap memenuhi syarat legal dan bobot buktinya.

Dokumen elektonik harus memiliki tingkat kepercayaan sebagai sebuah dokumen legal. Dengan diakuinya dokumen elektronik sebagai dokumen legal, maka dokumen elektronik dapat dijadikan bukti. Dalam konteks legal, sebuah bukti dapat berupa dokumentasi, perkataan, audio-visual, baik secara elektronik maupun bentuk lain.

Sebuah dokumen harus memiliki sifat sebagai sesuatu yang utuh dan akurat yang harus memiliki tiga karakteristik utama yaitu:

- Konten/kandungan:

Merupakan informasi yang membangun sebuah dokumen yang dapat berupa katakata, gambar, simbol, dan sebagainya.

- $\quad$ Konteks:

Lingkungan di luar konten yang turut serta dalam pembuatan, penerimaan, serta penggunaan sebuah dokumen yaitu lingkungan organisasi, fungsional, dan operasional.

- $\quad$ Struktur :

Format fisik dan logika sebuah dokumen serta hubungan antar elemen di dalamnya. 


\section{ALUR PROSES E-PROCUREMENT DEP. KIMPRASWIL (PEMUKIMAN PRASARANA WILAYAH)}

Pada tabel 1 di bawah ini terlihat masih ada beberapa tahapan yang diproses secara offline oleh karena itu penulis mencoba menganalisis dan membahas kendala-kendala dan pemecahannya terhadap suatu tahapan lelang yang belum dapat diproses secara online selain itu dibahas juga mengenai penyempurnaan terhadap suatu tahapan lelang yang sudah diproses secara online agar aplikasi e-procurement ini dapat berjalan secara optimal.

Tabel 1. Alur Proses Semi E-Procurement Dep. Kimpraswil

\begin{tabular}{|c|c|c|}
\hline No & Tahapan & Proses \\
\hline 1 & Pemaketan & $\mathrm{v}$ \\
\hline 2 & Pengumuman lelang & $\mathrm{v}$ \\
\hline 3 & Pendaftaran lelang & $\mathrm{v}$ \\
\hline 4 & PQ long list & $\mathrm{v}$ \\
\hline 5 & PQ short list & $\mathrm{v}$ \\
\hline 6 & Pengambilan dokumen lelang & $\mathrm{v}$ \\
\hline 7 & Anwijzing & o \\
\hline 8 & Pemasukan dokumen proposal/penawaran & o \\
\hline 9 & Pembukaan lelang & o \\
\hline 10 & Evaluasi & o \\
\hline 11 & Hasil penilaian administrasi & $\mathrm{v}$ \\
\hline 12 & Hasil penilaian teknis & $\mathrm{v}$ \\
\hline 13 & Hasil penilaian harga & $\mathrm{v}$ \\
\hline 14 & Pengumuman penetapan pemenang & $\mathrm{v}$ \\
\hline 15 & $\begin{array}{l}\text { Masa sanggah: } \\
\text { Sanggahan dan Jawabannya }\end{array}$ & $\mathrm{V}$ \\
\hline 16 & Penunjukan pemenang & $\mathrm{v}$ \\
\hline 17 & $\begin{array}{l}\text { Penayangan proposal/penawaran } \\
\text { bagi yang menang }\end{array}$ & $\mathrm{V}$ \\
\hline 18 & Informasi kontrak & $\mathrm{v}$ \\
\hline
\end{tabular}

Keterangan: $\mathrm{v}=$ on line $\mid \mathrm{o}=$ off line

Aplikasi e-procurement di departemen Kimpraswil dapat dikatakan cukup aplicable sesuai dengan data terbaru di Kimpraswil dimana penayangan tahapan lelang di internet mencapai 908 lelang dari 2.679 paket yang dikontrak-kan (33,89\%). Sementara 
itu, proyek yang dilakukan melalui e-procurement mencapai hampir $90 \%$ dari total lelang yang ada. Total rekanan yang memenuhi syarat untuk mengikuti lelang semi-eprocurement sudah mencapai 400 -an penyedia jasa.

\subsection{Pemaketan}

Sistem aplikasi e-procurement di situs Kimpraswil belum memberikan fasilitas untuk pengadaan paket pekerjaan di luar departemen Kimpraswil sehingga diharapkan pada pengembangannya mampu berafiliasi dengan departemen lain agar dapat menjadi fasilitator untuk pengadaan paket pekerjaan di luar departemen Kimpraswil.

\subsection{Pendaftaran Kualifikasi}

Pengisian data form tambahan prakualifikasi dengan cara mengupload file data prakualifikasi dalam format file word sebaiknya digantikan dengan metode pengisian data melalui form digital sehingga dapat memandu user untuk mengisikan data-data dengan lengkap dan benar selain itu data-data tersebut bisa langsung dikelola oleh suatu sistem aplikasi database sehingga waktu pemrosesan data relatif lebih cepat. Model formnya dapat berbentuk seperti pada tayangan di bawah ini.

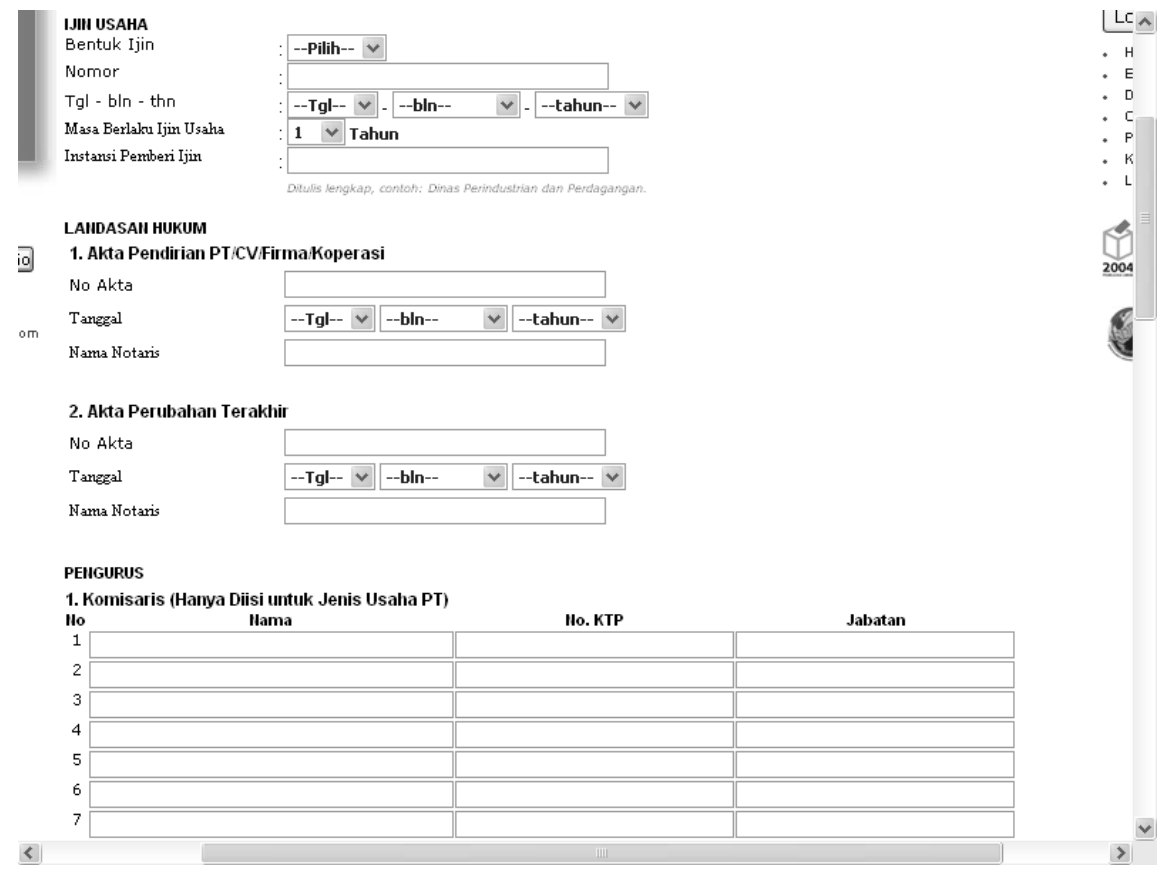

Gambar 2. model form prakualifikasi 


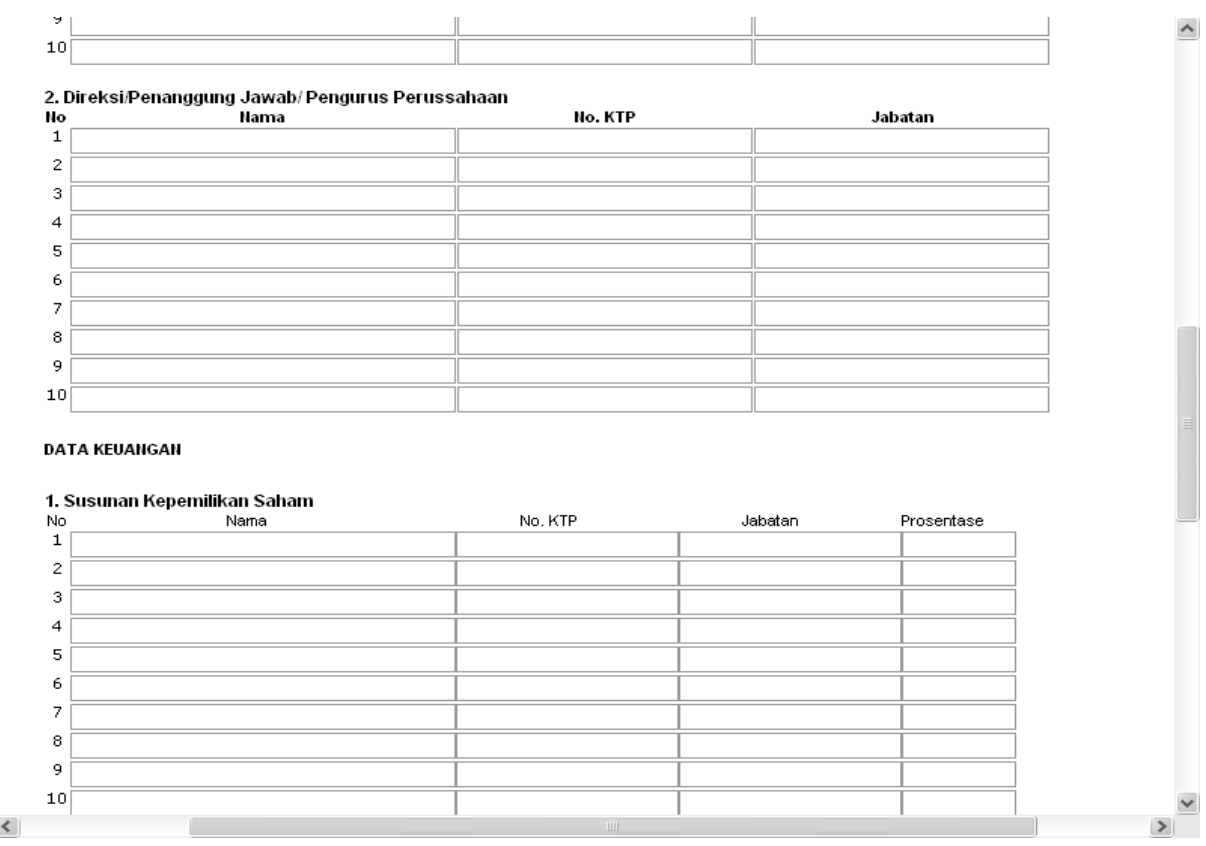

Gambar 3. Model Form Pengisian Data Prakualifikasi

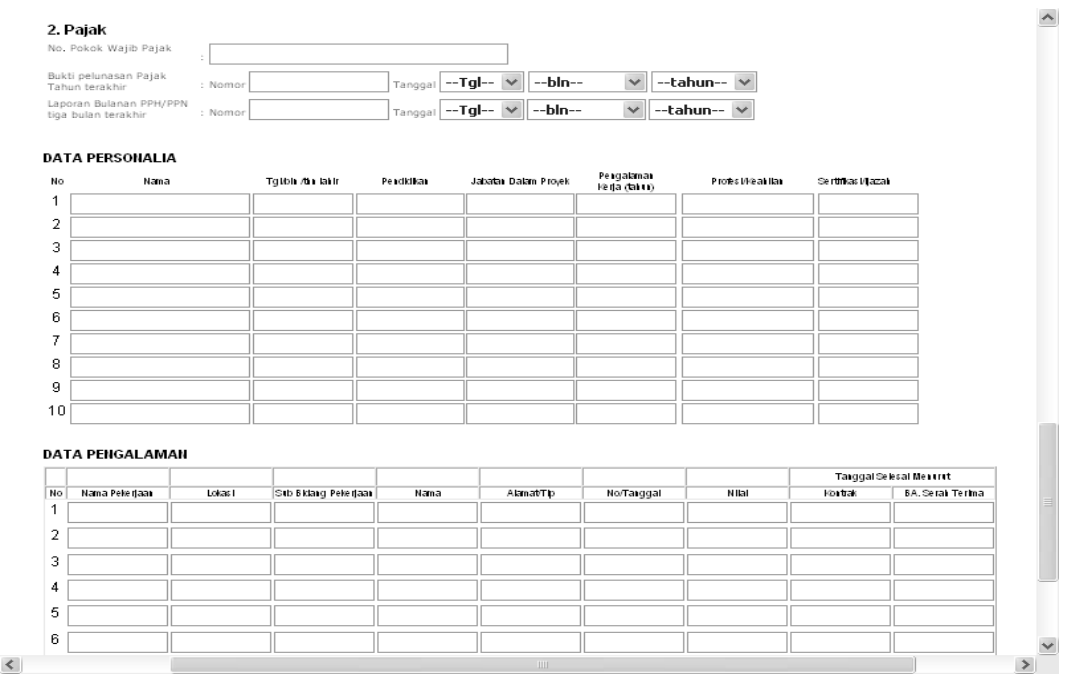

\section{Gambar 4. Model Form Pengisian Data Prakualifikasi (Lanjutan)}

Fasilitas untuk perbaikan data prakualifikasi melalui form pengisian dan upload file data prakualifikasi yang telah terkirim belum tersedia berbeda halnya dengan pemaketan dimana diberikan fasilitas untuk memperbaiki data paket pekerjaan yang dilelangkan. 
Untuk mencek kebenaran data yang diberikan peserta kualifikasi dapat memanfaatkan fasilitas cek kebenaran data yang disediakan oleh situs LPJK dan Departemen Perindustrian dan Perdagangan

Pada situs LPJK diberikan fasilitas untuk mencek kebenaran data SDM dan pengalaman suatu badan usaha seperti pada tayangan berikut

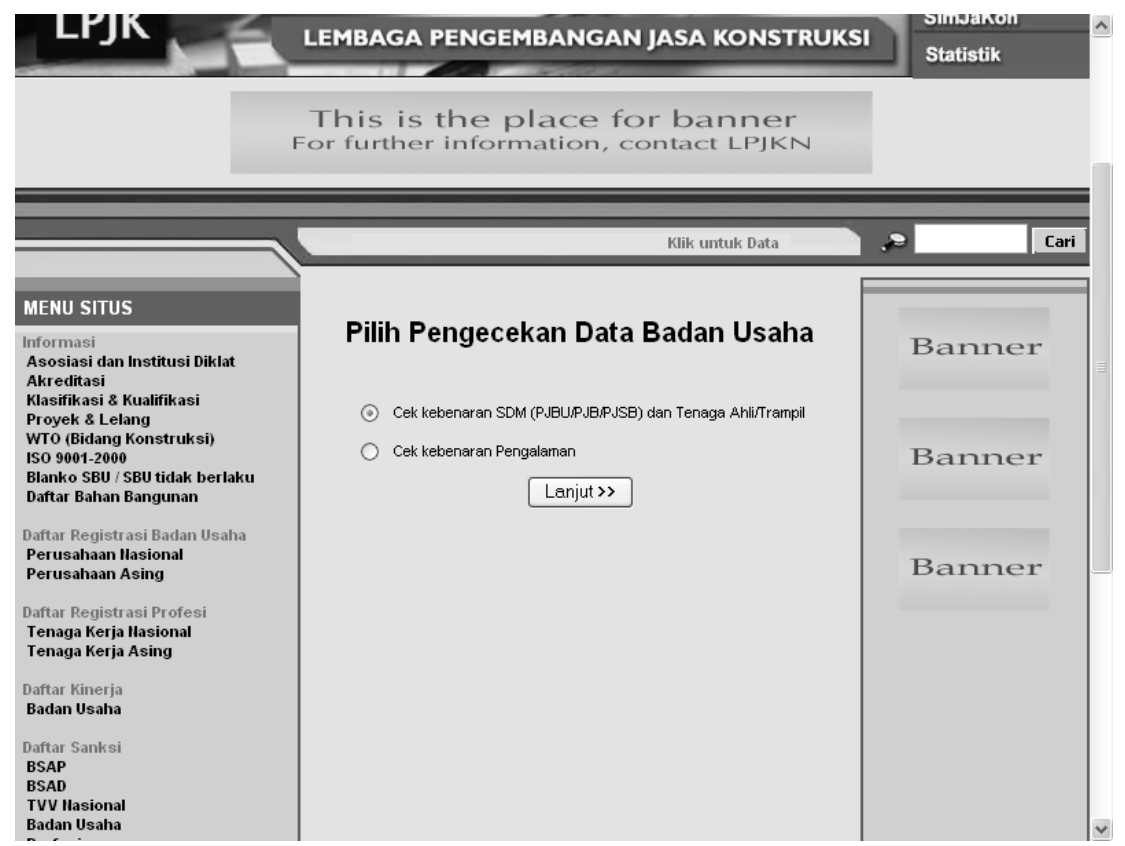

Gambar 5. Form Pengecekan Data Badan Usaha

\section{AANWIJZING (PENJELASAN PEKERJAAN )}

Aanwijzing belum bisa dilaksanakan secara online karena hal-hal sebagai berikut:

- Peninjauan lapangan tidak bisa diproses secara online

- $\quad$ Penjelasan dengan menggunakan fasilitas forum diskusi online dan chatting dinilai tidak efektif

Dengan begitu maka tahapan aanwijzing masih berjalan secara manual dan ada kontak langsung antar kontraktor sehingga masih membuka peluang $\mathrm{KKN}$ tetapi penulis berpendapat urusan KKN kembali ke moralitas masing-masing dan tak ada sistem yang seratus persen sempurna namun, setidaknya dapat meminimalkan KKN. Namun kekhawatiran akibat dari proses aanwijzing yang belum dapat dilaksanakan secara online sehingga kontak langsung antar kontraktor tak dapat dihindarkan ternyata untuk saat ini ditolong oleh Keppres no 80 tahun 2003 dimana mewadahi hal progressive dengan diberlakukannya suatu aturan baru yang menyebutkan tidak bisa digugurkannya 
penawaran calon penyedia barang/ jasa yang tidak hadir pada Aanwijzing yang diadakan panitia pengadaan. Sehingga calon kontraktor/ supplier yang tidak ingin hadir karena takut dipaksa kolusi antar mereka atau tidak bisa hadir karena alasan teknis dan jarak tetap bisa memberikan penawaran

\subsection{Pemasukan Dokumen Penawaran}

Proses tersebut belum bisa dilaksanakan secara online sehingga otomatis untuk tahap pembukaan dan evaluasi penawaran dilaksanakan secara offline. pemasukan dokumen penawaran belum bisa dilaksanakan secara online karena hal-hal sebagai berikut:

- Dokumen yang memerlukan legalisasi pihak lain seperti surat jaminan penawaran yang dilegalisasi oleh bank yang sebenarnya dapat diatasi dengan 2 cara yaitu:

* Dukungan pengesahan kelengkapan melalui media elektronik seperti materai digital, tanda tangan digital, bid bond dan bank guarantee, dll.

** Database Mitra Pendukung

* Dimana dokumen elektronik tersebut harus memiliki standar umum yang dapat mendukung interoperabilitas

** Merupakan tabel data untuk institusi pendukung pelaksanaan pengadaan barang/jasa, meliputi ; data identitas institusi dan personel yang terkait, data dukungan bank, data ijin usaha, data perpajakan dan data kelakuan baik/bebas sangsi pidana.

Keberadaan berbagai institusi pendukung dalam pelaksanaan pengadaan barang/jasa pemerintah yang bersifat sebagai pendukung dalam penyiapan dokumen secara integral dalam aplikasi yang dilengkapi dengan multilink system yang mampu menghubungkan berbagai komponen yang terkait secara interoperability. Ilustrasi dapat dilihat pada Gambar 6.

Legalisasi suatu dokumen dengan menggunakan metode database mitra pendukung lebih cepat dapat diimplementasikan karena tidak mengalami proses standarisasi dan registrasi yang kompleks selain itu metode database mitra pendukung dapat mempercepat proses pengolahan data.

Pemasukan dokumen penawaran secara online akan sangat strategis bila beberapa proses yang memungkinkan dapat di-otomatisasi seperti pencatatan terhadap data waktu, tanggal penerimaan dokumen penawaran, pemblokiran dokumen penawaran yang waktu pemasukannya melampaui waktu batas akhir sehingga tidak diperlukan konfirmasi untuk 
setiap penawaran yang diblokir kepada peserta lelang, dokumen penawaran pada surat penawaran untuk data seperti yang tidak memerlukan uraian yang panjang seperti jangka waktu berlaku surat penawaran, jangka waktu pelaksanaan pekerjaan sebaiknya diisikan melalui suatu form digital untuk memudahkan dalam pengolahan data sedangkan pada daftar kuantitas dan harga satuan sebaiknya dalam format file excel sehingga data-data bisa langsung diolah dan dievaluasi oleh suatu tools makro microsoft excel decision tools.

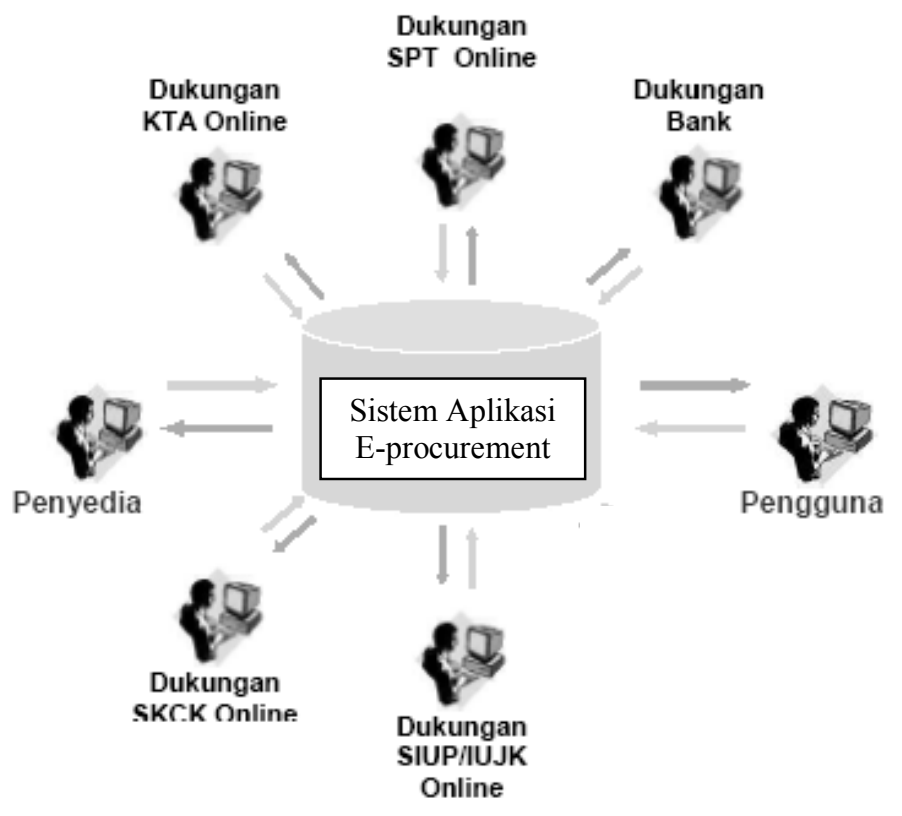

Gambar 6. Sistem Aplikasi E-procurement

Pada pengimplementasian fasilitas transaksi secara elektronik untuk fasilitas penyerahan formulir bahkan fasilitas pembayaran selain diperlukan suatu konsep dan sistem yang mendukung maka diperlukan juga suatu landasan peraturan perundangundangan yang berhubungan dengan pemanfaatan aplikasi e-procurement khususnya yang mengatur masalah keamanan dan kejahatan komputer atau kejahatan yang dilakukan menggunakan internet.

\section{KESIMPULAN dan SARAN}

\subsection{Kesimpulan}

1. Penerapan semi-e-procurement ini, membuat sebagian proses tatap muka, mulai dari tahap pengumuman, prakualifikasi, hingga pelelangan, berkurang dan digantikan internet. Baik itu untuk pengambilan formulir secara online, download 
dokumen lelang berita acara pembukaan dokumen lelang, hingga sanggahan sehingga dapat meminimalkan KKN namun penerapan semi-e-procurement masih membuka peluang KKN. Pasalnya, sebagian proses masih berjalan manual dan ada kontak langsung

2. Aplikasi sistem e-procurement memerlukan waktu dan proses bertahap, karena perubahan kebiasaan kerja yang fundamental serta kesiapan seluruh komponen yang terkait.

3. Apabila e-procure-ment sudah diterapkan secara penuh, maka:

a. Baik panitia maupun pengguna dapat melakukan interaksi terkait dengan tanggungjawab masing-masing secara lebih bebas, tanpa terbatasi oleh jarak dan waktu. Sehingga proses secara keseluruhan dapat diselesaikan dengan cepat.

b. Berbagai persyaratan dokumen, sarana dan prasarana pelelangan, honorarium staf, konsumsi, kurir dan hal-hal lain yang membutuhkan biaya dapat diminimalisir. Demikian pula untuk penyedia, berbagai aktifitas terkait dengan penyiapan persyaratan pelelangan yang akan diikuti juga dapat dilakukan dengan lebih hemat.

\subsection{Saran}

Agar pelaksanaan e-procurement optimal maka dalam sistem aplikasi E-

Procurement harus dilengkapi dengan :

1. Sistem Aplikasi

Perlu didukung aplikasi yang memiliki kemampuan interoperabilitas cukup bagus agar dapat menghubungkan berbagai komponen yang terkait dengan proses $e$ procurement..

2. Keamanan Sistem Aplikasi E-Procurement

Diantaranya adalah keamanan jaringan yang menjamin konektivitas yang aman, handal dan cepat termasuk tingkat proteksi keamanan dokumen elektronik yang memenuhi aspek legal dan bobot bukti.

3. Landasan Peraturan

Menyiapkan landasan peraturan yang mendukung implementasi pengadaan barang/jasa milik pemerintah secara elektronik. Menurut perkembangan terakhir Kementrian Kominfo dan Bappenas diketahui sedang menyiapkan landasan peraturan implementasi e-procurement yang direncanakan akan dikeluarkan dalam bentuk Keputusan Presiden (Keppres) . 


\section{DAFTAR PUSTAKA}

1. Ervianto Wulfram I., (2002), Manajemen Proyek Konstruksi, ANDI, Yogyakarta

2. Tim Penyusun Keppres, (2003), KEPPRES no. 80 tahun 2003 tentang Pedoman Pelaksanaan Pengadaan Barang/Jasa Pemerintah, CV. Tamika Utama, Jakarta.

3. Tim Penulis GIPI, (2004), Rating Web, http://gipi.go.id,

4. Tim Penulis Quantum eCommerce College, (2001), Diktat Kuliah Pemrograman Internet Dasar, Quantum eCommerce College, Bandung.

5. Tim Penulis Quantum eCommerce College, (2002), Diktat Kuliah Teknologi Server dan Jaringan, Quantum eCommerce College, Bandung.

6. Tim Penulis Quantum eCommerce College, (2002), Diktat Kuliah Web Design dan Tata Letak Web, Quantum eCommerce College, Bandung.

7. Tim Telematika Indonesia, (2003), Infrastruktur Informasi Elektronik, http://www.kominfo.go.id

8. Tim Telematika Indonesia, (2003), Manajemen Dokumen Elektronik, http://www.kominfo.go.id

9. Tim Telematika Indonesia, (2003), Pemerintah RI Dengan Seluruh Jajarannya Dapat Melaksanakan Pengadaan Barang/Jasa Secara Elektronik (EProcurement), http://www.kominfo.go.id

10. Tim Telematika Indonesia, (2003), Sistem Keamanan Jaringan, http://www.kominfo.go.id 